cate cases and tenses of the Russian language and cannot ask for a glass of water is invited to read sentences like "rubber similar to isoprene and other unsaturated hydrocarbons takes up bromine". The examples given in this book are mainly from the field of chemistry and physics. Scientists should not content themselves with only picking up a scientific jargon. Unless they know the fundamentals of the language they may misread a scientific article rather than read it. Once they have mastered ordinary Russian, the only additional book they will need is a suitable dictionary.

\section{Films and Film Strips in Teaching}

THE steady success of the educational films and film-strips produced by Gaumont-British Instructional Films, Ltd., now called Rank Precision Industries, Ltd., was due to clear recognition that they could never be more than aids to learning. The place of the teacher was accepted as paramount and all films and film-strips produced were deliberately designed to support the teacher rather than supplant him. As a result of this policy, Rank Precision Industries, Ltd., is now recognized as a valuable partner by the teaching profession in providing a wide range of both still and moving films. The latest film catalogue describes more than six hundred films in their separate categories with information about their content, running-time, suggested age-group, classification and hire- and purchase-prices. Besides films produced by Gaumont British Instructional, details are given of films produced by Encyclopædia Britannica Films, United World Films, and other organizations. In the film-strip catalogue more than three hundred strips are listed under eighteen subject categories; many of the films are in colour. Both catalogues are attractively produced and can be obtained from the Gaumont-British Film Library, Aintree Road, Perivale, Middlesex.

\section{'Araldite' in Aircraft Research Models}

Fon aerodynamic research, model aircraft of great accuracy and strength are required. A paper, pub. lished for the Royal Aircraft Establishment, Bedford, by the Ministry of Supply as Technical Note No. A.D.W.6, describes the making of models with shells consisting of 'Araldite' glasscloth laminate. It includes the results of bending tests on 'Araldite' glasscloth panels performed by the Royal Aircraft Establishment, Bedford. These tests show properties of laminates made with various 'Araldite' resins, glasscloth reinforcements and fillers. 'Araldite' epoxy resins, manufactured by Ciba (A.R.L.), Ltd., are extensively used in industry as adhesives, and for casting, laminating, tooling and surface coating. They were chosen by the Royal Aircraft Establishment, Bedford, for model-making because with glasscloth they give laminates with a very high strength/weight ratio. Several models of each type were required and the cold-laminating technique used resulted in these models being identical and of great dimensional accuracy. It is a feature of 'Araldite' epoxy resins that they cure with negligible shrinkage. A description of 'Araldite' and the uses to which it has been put at Bedford has been given by E. J. R. Thomas, of the Wood and Plastics Department (Ciba (A.R.L.), Ltd. Technical Notes No. 206 (February 1960): Model-Making with 'Araldite'. Pp. 12. Duxford : Ciba (A.R.L.), Ltd., $1960)$.

\section{Measurement of Wind Speeds near a Tornado}

AN observation has been made of the speed of debris particles whirling round a tornado funnel from enlargements of the separate pictures of a cine film. The maximum value was 212 m.p.h. The observation was made in a tornado which struck Dallas, Texas, on April 2, 1957. On enlargement of the film at the Kansas City Research Unit of the U.S. Weather: Bureau it proved possible to identify individual particles of debris whirling round the tornado and compute their tracks and speeds. The observations are reported in the October 1959 issue of the Monthly Weather Review.

\section{The Neolithic Revolution}

Recentiy, a British Museum (Natural History) publication entitled "The Neolithic Revolution" has appeared (Pp. vi $+60+18$ plates. London: British Museum (Natural History), 1959. 5s.). The author, Sonia Cole, is well known for her work on certain aspects of African prehistory. The discovery by early man of the possibilities of agriculture and the breeding of animals in captivity produced profound changes not only in his well-being, but also in his outlook on life. This neolithic revolution necessitated communal life, and for the first time man had to live close to his fellow man-not always an easy matter. Food could now be stored and a much larger population could survive. It is not too much to say that we can describe the prehistoric folk prior to these discoveries as our forerunners, those that come after them as our early ancestors. 'This well-illustrated work discusses such problems as the origins of grain cultivation, the domestication of animals - that is to say, breeding in captivity, not merely taming; flint mining and forest clearance ; transport-particularly necessary when a further stage in civilization was reached and the village developed into the town; crafts and buildings.

\section{Fishery Research Training Grants}

THe Development Commissioners have announced that, in association with the Ministry of Agriculture, Fisheries and Food and the Scottish Home Department, they will award postgraduate training grants in fishery research tenable from October 1. These training grants are intended to enable selected candidates to undergo a specified course of training to fit them for the investigation of problems in marine or freshwater science. Candidates must be British subjects and should be graduates with honours in science of a British university or possess equivalent qualifications. The value of the awards will be £420-£270 per annum depending on where the research training is carried out. Further information can be obtained from the Secretary, Development Commission, 3, Dean's Yard, Westminster, London, S.W.1. Applications should reach the Commissioners on or before May 20.

\section{The British Textile Institute}

THE Textile Institute celebrates its golden jubilee this year, and in its awareness of the importance of science in the textile industry the theme of the annual conference will be "Fibre Science". The meet ing will be held in London during May 30-June 3. The conference will be opened by Sir Harry Melville, who will speak on the impact of modern chemistry on industry in general. Other speakers will include Prof. J. B. Speakman (University of Leeds), Prof. 